\title{
Signal Peptide-Selection of cDNA Cloned Directly from the Esophageal Gland Cells of the Soybean Cyst Nematode Heterodera glycines
}

\author{
Xiaohong Wang, ${ }^{1}$ Rex Allen, ${ }^{2}$ Xiongfei Ding, ${ }^{2}$ Melissa Goellner, ${ }^{1}$ Tom Maier, ${ }^{3}$ Jan M. de Boer, ${ }^{3}$ \\ Thomas J. Baum, ${ }^{3}$ Richard S. Hussey, ${ }^{2}$ and Eric L. Davis ${ }^{1}$ \\ ${ }^{1}$ Department of Plant Pathology, North Carolina State University, Box 7616, Raleigh 27695-7616, U.S.A.; \\ ${ }^{2}$ Department of Plant Pathology, University of Georgia, Athens 30602-7274, U.S.A.; ${ }^{3}$ Department of Plant \\ Pathology, lowa State University, 351 Bessey Hall, Ames 50011, U.S.A. \\ Accepted 14 December 2000.
}

\begin{abstract}
Secretions from the esophageal gland cells of plantparasitic nematodes play critical roles in the nematodeparasitic cycle. A novel method to isolate cDNA encoding putative nematode secretory proteins was developed that utilizes mRNA for reverse transcription-polymerase chain reaction derived from microaspiration of the esophageal gland cell contents of parasitic stages of the soybean cyst nematode Heterodera glycines. The resulting $\mathrm{H}$. glycines gland cell cDNA was cloned into the pRK18 vector, and plasmid DNA was transformed into a mutated yeast host for specific selection of cDNA inserts that encode proteins with functional signal peptides. Of the 223 cDNA clones recovered from selection in yeast, $97 \%$ of the clones encoded a predicted signal peptide. Fourteen unique cDNA clones hybridized to genomic DNA of $\mathrm{H}$. glycines on Southern blots and, among them, nine cDNA clones encoded putative extracellular proteins, as predicted by PSORT II computer analysis. Four cDNA clones hybridized to transcripts within the dorsal esophageal gland cell of parasitic stages of $\mathrm{H}$. glycines, and in situ hybridization within $H$. glycines was not detected for eight cDNA clones. The protocol provides a direct means to isolate potential plant-parasitic nematode esophageal gland secretory protein genes.
\end{abstract}

Additional keywords: expressed sequence tags, functional genomics, host-parasite interactions, nematode feeding sites, parasitism genes.

Secretory proteins that are synthesized within the esophageal gland cells of plant-parasitic nematodes are secreted from the nematode through its stylet (hollow mouth spear). Secretions from the esophageal gland cells appear to have multiple biological functions during the plant nematode life cycle (Davis et al. 2000; Hussey 1989a). Some of the potential functions of nematode secretions include the processes of

Corresponding author: E. L. Davis; Telephone: +1-919-515-6692; Fax: +1-919-515-7716; E-mail: eric_davis@ncsu.edu

Nucleotide sequences of Heterodera glycines cDNA are available in GenBank (accession numbers listed in Table 1). plant root penetration, migration within host tissues, and the modification of host plant cells into complex permanent feeding sites that are essential for sustained nematode nutrition (Davis et al. 2000; Hussey 1989a). The three esophageal gland cells of plant nematodes are relatively large, localized within the anterior portion of the nematode, and connected through elaborate valves to the lumen of the esophagus (and stylet). These secretory gland cells change dramatically in morphology and activity throughout parasitism of plants by sedentary endoparasitic nematodes (Hussey 1989a). In preparasitic nematode juveniles, the two subventral esophageal gland cells are large and packed with secretory granules, whereas the one dorsal esophageal gland cell is relatively small and contains few secretory granules. After host root penetration and initiation of a feeding site, however, the nematode becomes sedentary, the subventral glands atrophy, and the dorsal gland enlarges and becomes packed with secretory granules (Endo 1987; Endo 1993; Wyss 1992; Wyss and Zunke 1986). These morphological modifications suggest that the contents and functions of these two types of secretory gland cells change during nematode parasitism of its host.

Efforts to isolate and characterize the components of plantparasitic nematode esophageal gland secretions have been hindered by the nematode's small size and obligate parasitic nature. A number of monoclonal antibodies have been developed that bind to different antigens within nematode esophageal gland cells (Atkinson et al. 1988; Davis et al. 1992; De Boer et al. 1996; Goverse et al. 1994; Hussey 1989b). Some of the monoclonal antibodies have been used to demonstrate the differential expression of esophageal gland antigens in several nematode parasitic stages (Davis et al. 1994; Goverse et al. 1994). Two cDNAs encoding $\beta$-1,4-endoglucanases were isolated from the cyst nematodes Globodera rostochiensis and Heterodera glycines (Smant et al. 1998) utilizing the $\mathrm{N}$-terminal amino acid sequence of a nematode protein that was immunoaffinity purified with a subventral gland-specific monoclonal antibody MGR 48 (De Boer et al. 1996). The developmental expression and secretion of these endoglucanases by infective juveniles of $H$. glycines within soybean roots (De Boer et al. 1999; Wang et al. 1999) demonstrates the direct involvement of these secreted enzymes in nematode intracellular migration within host tissue. 
Relatively few plant-parasitic nematode esophageal gland secretory proteins have been isolated and identified to date, even though a number of monoclonal antibodies against different nematode esophageal gland secretions are available (Davis et al. 2000). The epitope specificity of the glandspecific monoclonal antibodies, however, has limited the recovery of potential secretion gene clones from the screening of plant-parasitic nematode cDNA expression libraries. Screening for genes expressed specifically in the anterior gland region versus the (glandless) posterior sections of plant nematodes or between differential nematode life stages has been employed to clone genes that are expressed specifically in the nematode esophageal gland cells (Ding et al. 1998; Lambert et al. 1999). Expressed sequence tag (EST) analyses recently have been combined with the cDNA-amplified fragment length polymorphism of selected $G$. rostochiensis life stages to obtain several cDNA clones with transcripts that are expressed in the nematode esophageal gland cells (Qin et al. 2000). Although differential screening methods have been successful, they may be relatively inefficient. This paper reports a novel method used to comprehensively clone potential $H$. glycines secretory protein cDNAs directly from the esophageal gland cells by cellular microaspiration and reverse transcription-polymerase chain reaction (RT-PCR) combined with a eukaryotic signal peptide selection system. To date, the method has provided the most direct and efficient means to clone putative plant nematode esophageal gland cell secretory protein genes.

\section{RESULTS}

Construction of the esophageal gland cell cDNA library.

The contents of ten esophageal gland cells microaspirated from the parasitic $\mathrm{J} 2, \mathrm{~J} 3$, and $\mathrm{J} 4$ stages of $H$. glycines were used for mRNA purification and cDNA library construction. Poly A(+) RNA was purified with oligo(dT)-linked magnetic beads to optimize the recovery of the minute amounts of mRNA from the ten gland cells and minimize contamination by nonpoly $\mathrm{A}(+)$ RNA. Synthesis of first-strand cDNA with random hexamers increased the likelihood of obtaining a $5^{\prime}$ end signal peptide sequence and decreased the likelihood of producing stop codons in the pRK18 vector compared with oligo(dT) priming.

Agarose gel analysis revealed that less than $10 \mathrm{ng}$ of products were obtained from the initial RT-PCR, after starting with template mRNA from ten cells. This necessitated a second PCR of a portion of the initial products to produce enough cDNA to be cloned into the pRK18 signal peptide selection vector. pRK18 was excised from the $\lambda \mathrm{RK} 18$ vector that contained a modified invertase gene and lacked the region encoding an initiator methionine and signal peptide (Klein et al. 1996). The efficiency of cDNA cloning of the resulting pRK18 H. glycines gland cell library into Escherichia coli was about $88 \%$, and insert sizes ranged from $90 \mathrm{bp}$ to $2 \mathrm{~kb}$ of the 96 clones that were selected at random for cDNA insert size and sequence confirmation.

\section{Selection of $\mathrm{H}$. glycines cDNA with functional signal peptides.}

In wild-type Saccharomyces cerevisiae, a secreted invertase functions extracellularly to catalyze the breakdown of sucrose and allow the yeast to use sucrose in the medium as a carbon source. The $\mathrm{Ura}^{-}$and invertase-deficient $S$. cerevisiae host YT455, when transformed with the $\mathrm{Ura}^{+}$pRK18 vector, is able to grow on a sucrose medium only when a cDNA encoding a protein with signal peptide is cloned in-frame with the invertase of the pRK18 vector (Klein et al. 1996). $\mathrm{Ura}^{+}$selection of $S$. cerevisiae strain YT455 transformed with plasmid

Table 1. Summary of fourteen unique cDNA clones from Heterodera glycines isolated after yeast signal peptide selection

\begin{tabular}{|c|c|c|c|c|c|c|c|}
\hline $\begin{array}{l}\text { Clone } \\
\text { name }\end{array}$ & $\begin{array}{r}\text { GenBank } \\
\text { accession }^{\mathrm{a}}\end{array}$ & $\begin{array}{c}\text { cDNA } \\
\text { size (bp) }\end{array}$ & Homology search & $\begin{array}{c}\text { BLASTp } \\
\text { score/E value }\end{array}$ & $\begin{array}{c}\text { Signal } \\
\text { peptide }^{b}\end{array}$ & $\begin{array}{l}\text { PSORT II } \\
\text { prediction }^{c}\end{array}$ & $\begin{array}{c}\text { In situ } \\
\text { hybridization }\end{array}$ \\
\hline SYV46 & AF273728 & $607^{\mathrm{e}}$ & Pioneer & & Yes & Extracellular & DG \\
\hline SY20 & AF273729 & 483 & Pioneer & & Yes & Extracellular & DG \\
\hline SYS7 & AF159590 & $647^{e}$ & $\begin{array}{l}\text { Hypothetical } 15.0-\mathrm{kD} \text { a protein } \\
\text { (Caenorhabditis elegans) }\end{array}$ & $165 / 3 \mathrm{E}^{-40}$ & Yes & Extracellular & ND \\
\hline SYS16 & AF273730 & 356 & $\begin{array}{l}\text { Transglutaminase precursor (Dirofilaria } \\
\quad \text { immitis) }\end{array}$ & $127 / 4 \mathrm{E}^{-29}$ & Yes & Extracellular & ND \\
\hline SYS56 & AF273731 & $1,418^{\mathrm{e}}$ & Pioneer & & Yes & Extracellular & Lateral ganglia \\
\hline SYS65 & & 478 & Guanylyl cyclase $(H$. glycines $)$ & $176 / \mathrm{E}^{-43}$ & Yes & Nuclear & DG \\
\hline SYS79 & AF273732 & 602 & Pioneer & & Yes & Extracellular & ND \\
\hline SYS86 & AF273733 & $907^{\mathrm{e}}$ & Hypothetical protein (C. elegans) & $152 / 3 \mathrm{E}^{-36}$ & Yes & ER & ND \\
\hline SYS91 & AF273734 & 612 & $\begin{array}{l}\text { Thiol:disulfide interchange protein DsbC } \\
\quad(\text { Pseudomonas aeruginosa) }\end{array}$ & $219 / \mathrm{E}^{-56}$ & No & Not applicable & ND \\
\hline SYV42 & AF273735 & 584 & ERp99 (Mus musculus) & $144 / 4 \mathrm{E}^{-34}$ & Yes & Extracellular & DG, germ line \\
\hline SYV52 & & 341 & $\begin{array}{l}\text { Beta-1,4-endoglucanase-1 precursor ( } H \text {. } \\
\text { glycines })\end{array}$ & $113 / 3 \mathrm{E}^{-25}$ & No & Not applicable & $\mathrm{SvG}$ \\
\hline SYV55 & AF159591 & $797^{\mathrm{e}}$ & $\begin{array}{l}\text { Metalloproteinase inhibitor } 2 \text { precursor ( } C \text {. } \\
\text { elegans) }\end{array}$ & $94 / \mathrm{E}^{-18}$ & Yes & Extracellular & ND \\
\hline SYV80 & AF273736 & 701 & Pioneer & & Yes & Extracellular & ND \\
\hline SYV84 & AF273737 & 601 & Pioneer & & Yes & Nuclear & ND \\
\hline
\end{tabular}

a New sequences submitted to GenBank, with the exception of AF095746 and AF006052, which were submitted previously.

${ }^{\mathrm{b}}$ Presence of a signal peptide, as predicted by computer analysis (Nielsen et al. 1997).

c Subcellular localization, as predicted by PSORT II computer analysis (Nakai and Horton 1999). PSORT II analysis is not applicable to cDNA that lack a predicted signal peptide. ER = endoplasmic reticulum.

${ }^{\mathrm{d}}$ Hybridization of cDNA to transcripts specifically within the dorsal esophageal gland cell (DG), subventral esophageal gland cells (SvG), other structure listed, or no hybridization detected (ND) within specimens of $H$. glycines.

e Size listed represents full-length cDNA sequence. All other sequences are partial cDNA. 
DNA from the pRK18 $\mathrm{H}$. glycines cDNA library was used as an initial selection and yielded approximately 100,000 to 200,000 yeast colonies. Minimizing the selection time on uracil-deficient medium to an overnight incubation and the inclusion of antimycin A to simulate anaerobic growth conditions is critical to reduce the appearance of subsequent false positives. Of the total yeast colonies recovered on uracildeficient medium, only 223 colonies were able to grow on sucrose medium, whereas $97 \%$ (216) of the 223 cDNA sequences were found to encode proteins with predicted signal peptides (Nielsen et al. 1997) and fused in-frame with the vector invertase gene. The cloning and selection were so efficient that only five copies of a putative ribosomal small subunit RNA gene (data not shown) and two additional cDNA sequences (SYV52 and SYS91), without putative signal peptides, were obtained among the 223 clones. Clone SYV52 was a significant match to the endoglucanase gene that had been cloned previously from the subventral esophageal gland cells of $H$. glycines (Smant et al. 1998). Twenty-eight unique cDNA sequences were obtained from the 223 clones, and 14 of the unique cDNAs (Table 1) hybridized to genomic DNA of H. glycines on Southern blots.

\section{Predicted subcellular localization}

of $\boldsymbol{H}$. glycines proteins with signal peptides.

Only full-length sequences of SYV46, SYV55, SYS7, SYS56, and SYS86 (Table 1) could be obtained with 3' rapid amplification of cDNA ends (RACE). Sequence analysis of the predicted peptides encoded by these full-length cDNAs did not reveal homology to any known proteins in BLASTp, with the exception of SYV55, which encoded a protein with homology to a metalloproteinase inhibitor 2 precursor from Caenorhabditis elegans (C. elegans Sequencing Consortium 1998). The peptides encoded by SYV46, SYV55, SYS7, and SYS56 were all predicted to be extracellular by PSORT II analysis, which is designed to predict the subcellular localiza-
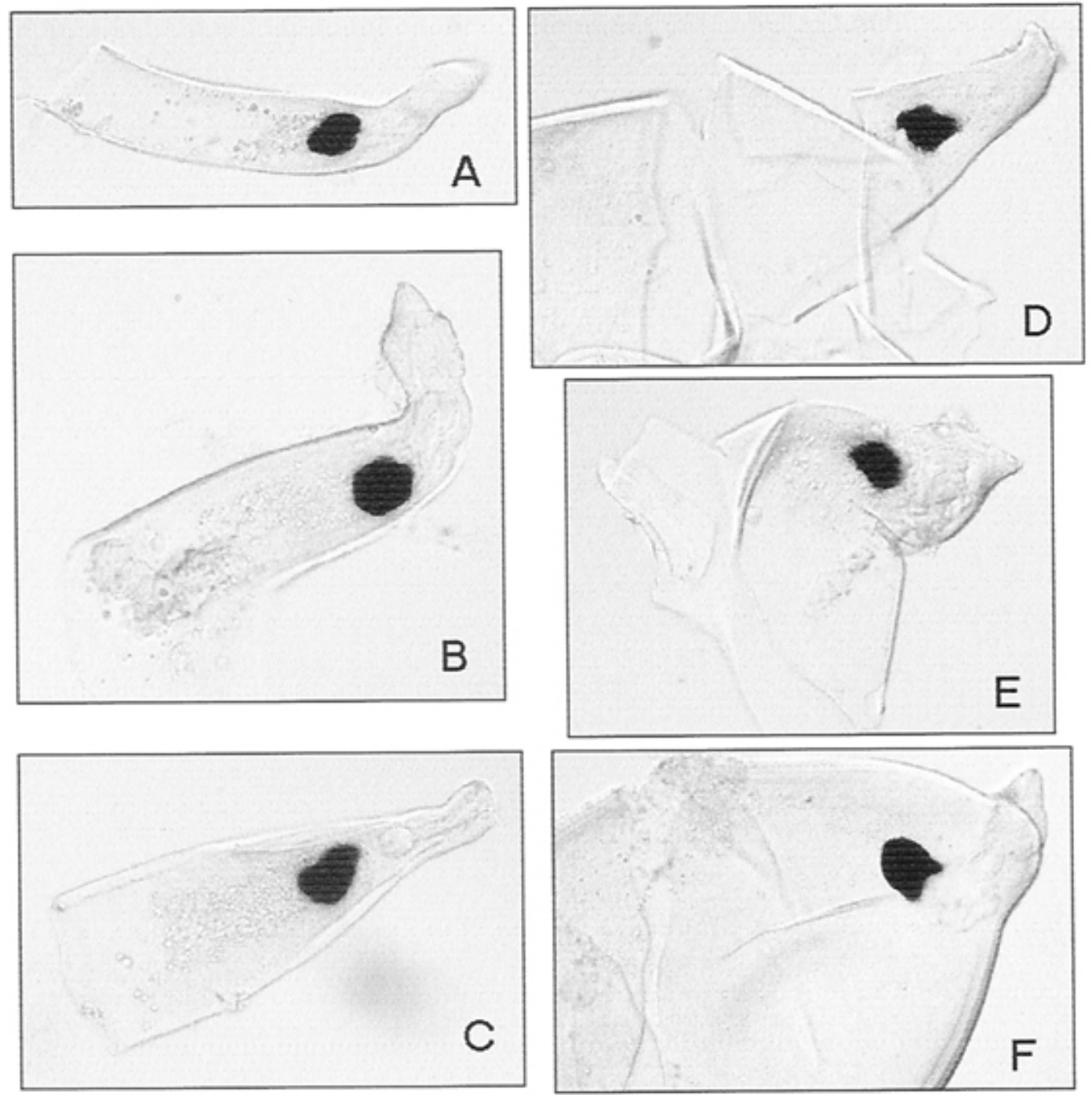

Fig. 1. Hybridization of a digoxygenin-labeled antisense cDNA probe (dark staining) of clone SYV46 (Table 1) to mRNA expressed exclusively within the dorsal esophageal gland cell of the soybean cyst nematode Heterodera glycines. In situ hybridization was observed only in parasitic stages of $H$. glycines that were dissected from host plant roots and included parasitic A, second-stage juveniles, B, Third-stage juveniles, $\mathbf{C}$ and $\mathbf{D}$, fourth-stage juveniles, and $\mathbf{E}$ and $\mathbf{F}$, young adult females. 
tion sites of proteins (Nakai and Horton 1999). The peptide encoded by SYS86 was predicted to be an endoplasmic reticulum (ER) protein by PSORT II analysis.

Subcellular localization of peptides encoded by the $H$. glycines partial cDNA clones SY20, SYV42, SYV80, SYV84, SYS16, SYS65, and SYS79 also were evaluated by the PSORT II program. Peptides encoded by SY20, SYV42, SYV80, SYS16, and SYS79 were predicted to be extracellular, whereas peptides encoded by SYV84 and SYS65 were predicted to have nuclear localization. The peptide encoded by SYV42 had homology to an ER protein of Mus musculus (Mazzarella et al. 1987). Because the C-terminal regions of the partial cDNA sequences were not available, full-length sequences need to be obtained to further analyze the potential subcellular localization and database homology of each predicted peptide.

\section{In situ localization of genes expressed within specimens of $\mathrm{H}$. glycines.}

The digoxygenin-11-dUTP (DIG)-labeled antisense cDNA probe of clone SYV46 gave an immediate and strong in situ hybridization signal specifically within the enlarged dorsal esophageal gland cell of parasitic H. glycines (Fig. 1). Hybridization of the SYV46 probe exclusively within the dorsal gland cell was consistent in second-, third-, and fourth-stage parasitic juveniles as well as in young females of $H$. glycines. Hybridization specifically within the dorsal esophageal gland cell also was obtained with the antisense cDNA probes of clones SY20 (Fig. 2) and SYS65. The hybridization signal in the dorsal gland cell was observed only in third-stage juveniles and in subsequent developmental female stages of $H$. glycines for SY20 and SYS65. The antisense probes of SYV46 and SY20 did not hybridize to the esophageal gland cells nor to any structure in the preparasitic juveniles of $H$. glycines (data not shown). No hybridization signal was detected within $H$. glycines specimens with the antisense cDNA probes of SYS7, SYS16, SYS79, SYS86, SYS91, SYV55, SYV80, and SYV84. The antisense cDNA probe of SYS56 hybridized within the lateral ganglia of the nervous system of $H$. glycines but not within the esophageal gland cells. Hybridization within the dorsal esophageal gland cell and germline cells of developing $H$. glycines females were observed with the SYV42 antisense probe (data not shown). The control-sense cDNA probes of all clones did not hybridize within specimens of $H$. glycines (data not shown).

\section{DISCUSSION}

The identification of secretory protein gene products that are expressed developmentally within the esophageal gland cells of plant-parasitic nematodes is critical to understand the molecular basis of compatible plant-nematode interactions. We were successful in targeting the esophageal gland cells with the use of a microneedle specifically to aspirate the gland cell contents. The pooling of gland cell contents from different parasitic stages of $H$. glycines enabled the construction of a cDNA library that represented gene expression more comprehensively during the parasitic cycle of $H$. glycines. Penetration of the microneedle into immobilized, viable parasitic stages of $H$. glycines was relatively easy because the longitudinal muscles of the nematode body wall degenerate and the basal zone of the cuticle degrades as the established parasite becomes swollen and sedentary (Hussey and Grundler 1998). It has proven to be more difficult to penetrate the structurally complete body wall of preparasitic juveniles of $H$. glycines with a microneedle (R. S. Hussey, unpublished). The preparasitic
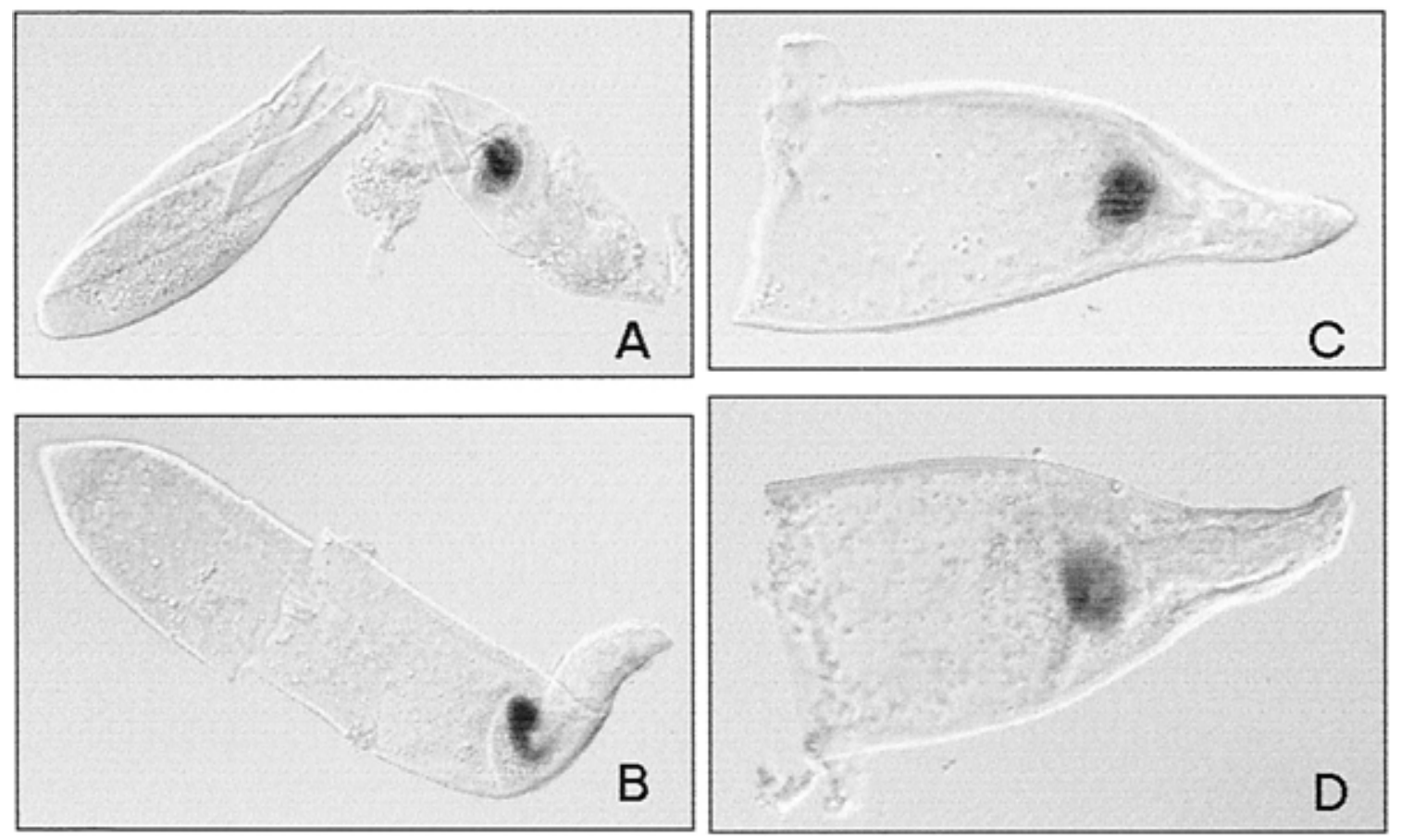

Fig. 2. Hybridization of a digoxygenin-labeled antisense cDNA probe (dark staining) of clone SY20 (Table 1) to mRNA expressed exclusively within the dorsal esophageal gland cell of the soybean cyst nematode Heterodera glycines. In situ hybridization was observed only in parasitic stages of $H$. glycines that were dissected from host plant roots and included parasitic $\mathbf{A}$, third-stage juveniles, $\mathbf{B}$, fourth-stage juveniles, and $\mathbf{C}$ and $\mathbf{D}$, young adult females. 
juvenile life stage is when the subventral esophageal gland cells are relatively active (Hussey 1989a).

Secretory proteins synthesized within the nematode esophageal gland cells should contain an N-terminal signal peptide sequence targeted to the secretory pathway (Von Heijne 1985). The secretion signal peptide has three characteristic regions: a positively charged $\mathrm{N}$-terminal region, a central hydrophobic region, and a more polar C-terminal region (Von Heijne 1985). Selection with the pRK18 vector system in yeast (Klein et al. 1996) efficiently reduced the relatively large $H$. glycines gland cell cDNA pool to be analyzed, and $97 \%$ of the peptides encoded by the yeast-selected cDNA clones contained putative signal peptides. Because both secreted and transmembrane proteins can be obtained through the pRK18 signal peptide selection system (Klein et al. 1996), the subcellular-localization program PSORT II (Nakai and Horton 1999) was employed to analyze $H$. glycines cDNA clones with predicted signal peptides. PSORT II predicted that nine of the 12 unique cDNA clones with signal peptides that were positive on $H$. glycines Southern blots encoded peptides that were extracellular. Database homologies of some clones, however, did not always agree with PSORT II predictions. For example, the peptide encoded by the partial cDNA of SYV42 was predicted to be extracellular, but it had homology to an ER protein of Mus musculus, which suggests an intracellular function of this protein. Similarly, the peptide encoded by the partial cDNA of SYS16 was predicted to be extracellular and had homology to a transglutaminase precursor of Dirofilaria immitis (Chandrashekar et al. 1998; Chandrashekar et al. 2000). The D. immitis protein, however, has significant homology to the ERp60 protein found in the lumen of the endoplasmic reticulum. Interestingly, transglutaminase is reported to catalyze posttranslational modifications that may play an important role in the synthesis of a new cuticle during the growth and maturation of filarial nematode parasites (Chandrashekar et al. 1998; Chandrashekar et al. 2000). Transglutaminase activity also has been detected in various developmental stages of the free-living nematode $C$. elegans (Chandrashekar et al. 2000). Whether the protein encoded by SYS16 is intracellular and involved in $H$. glycines cuticle formation or if the protein is a secreted esophageal gland cell protein of $H$. glycines with a potential role in plant parasitism remains to be determined. More definitive subcellular localization of the peptides encoded by the $H$. glycines cDNA clones can be determined through the use of specific antisera raised to the recombinant products of each cDNA clone.

Sequence analysis revealed that the protein encoded by the full-length cDNA of SYV55 had homology to a tissue inhibitor of metalloproteinases (TIMP)-2 (C. elegans Sequencing Consortium 1998). Mammalian TIMPs are secreted from cells to bind to the matrix metalloproteinases (MMPs) in tissue or cell peripheries and regulate several biological functions, including inhibition of active MMPs, proMMP activation, and cell-growth promotion (Brew et al. 2000). Although the peptide encoded by SYV55 is predicted by PSORT II to be extracellular, no research describing the function of nonmammalian TIMPs has been reported that can be used for comparative purposes.

It is interesting to note that one of the cDNA clones selected was apparently the endoglucanase gene previously cloned from the subventral esophageal gland cells of $H$. glycines
(Smant et al. 1998). This confirmed that the starting material was from $H$. glycines esophageal gland cells and that some subventral gland cell contents were present in the initial pool. It is uncertain why clones encoding the apparent endoglucanase (SYV52), a putative bacterial thiol-disulfide interchange protein (SYS91), and five duplicates of a putative cyst nematode small subunit RNA clone escaped pRK18 selection in the apparent absence of a signal peptide, but these were rare events. The endoglucanase genes of $H$. glycines are reported to contain secretion signal peptides (Smant et al. 1998), and clones SYV52 and SYS91 hybridized to genomic DNA of $H$. glycines on Southern blots.

The lack of Southern blot hybridization to $H$. glycines DNA by 14 of the 28 unique cDNA clones that survived signal peptide selection was apparently a result of microbial contamination. Most of the foreign clones appeared to be of bacterial origin and may have been a result of the greenhouse origin of the nematode-starting materials, despite efforts to decontaminate. All of the contaminant clones, however, did possess a predicted signal peptide. It is worthy to note that one partial cDNA clone, SYS91, which was positive on $H$. glycines Southern blots, had its strongest similarity to a bacterial thioldisulfide interchange protein DsbC (Stover et al. 2000). The dsbC gene encodes a periplasmic protein with disulfide isomerase activity that catalyzes disulfide bond formation in prokaryotes (Bardwell et al. 1994). It has been hypothesized that ancestors of some cyst nematode genes (i.e., endoglucanases) may have been acquired from prokaryotic sources via horizontal gene transfer (Davis et al. 2000; Smant et al. 1998; Yan et al. 1998). Characterization and functional studies of SYS91 need to be conducted to investigate any potential involvement of this gene product in nematode parasitism.

The problem of redundancy was observed only among a handful of the total number of cDNA clones that were recovered after signal peptide selection in yeast. For example, 43 duplicates of clone SYS65 were present among the 223 clones recovered. The second PCR used to amplify the initial gland cell RT-PCR products may have favored the amplification of abundant messages. Redundancy also may have been caused by a disproportional preference of PCR amplification. Normalization of the esophageal gland cell cDNA library before yeast transformation would likely decrease the redundancy of certain genes as well as increase the chances of obtaining rare transcripts.

In situ hybridization demonstrated the specific expression of SYV46, SY20, and SYS65 cDNA clones within the dorsal esophageal gland cell of parasitic stages of $H$. glycines. These observations further confirmed the gland cell origin of the starting material. Interestingly, the expression of these genes could be detected only after nematodes had parasitized host roots. The developmental expression among clones SYV46, SY20, and SYS65 also differed among the parasitic stages of $H$. glycines. These data demonstrate the representative nature of the parasitic cycle within the gland cell cDNA library and suggest that the regulation of some putative parasitism genes requires stimulation by factors within host tissue. Clones SYV46 and SY20 had no significant BLASTp matches, but clone SYS65 had strong similarity to a guanylyl cyclase previously isolated from $H$. glycines (Y. Yan and E. L. Davis, unpublished) (GenBank accession no. AF095746). Guanylyl cyclases exist in membrane-bound and soluble intracellular 
forms; catalyze the conversion of GTP to cGMP; and play a role as receptors and intermediates in a variety of cellular signaling events, including nematode chemoreception (L'Etoile and Bargmann 2000; Lucas et al. 2000; Yu et al. 1997). The peptide encoded by the partial cDNA of clone SYS65 has a predicted nuclear localization, but transcript of the gene was abundant throughout the dorsal gland cell cytoplasm. Whether this putative guanylyl cyclase plays a role in activation of the gland cell or has a role in plant parasitism is unclear at present. In situ localization of the expression of SYS56 only within lateral nerve ganglia may represent the product of mRNA that was inadvertently acquired as the microneedle passed through the nematode body. Alternatively, SYS56 may be the product of a gene that also is expressed in the esophageal gland cells of $H$. glycines but was not detected by the in situ method used here. The expression of genes in more than one cell type was illustrated by in situ localization of clone SYV42 in the dorsal gland cell and germ-line cells of $H$. glycines females. Lack of hybridization of some probes may be the result of differences in template, probe design, and hybridization conditions that need to be modified on a genespecific basis. For rare transcripts, more sensitive methods such as in situ RT-PCR may need to be employed to localize gene expression within specimens of $H$. glycines.

A pool of cDNA generated by RT-PCR from the microaspirated contents of $H$. glycines esophageal gland cells coupled with a signal peptide selection system offers a direct means to isolate potential plant nematode esophageal gland secretory protein genes compared with differential screening methods (Ding et al. 1998; Lambert et al. 1999; Qin et al. 2000). It should be noted that a relatively small aliquot (approximately $5 \%$ ) of the initial RT-PCR product was subjected to a second amplification and only 5 to $10 \%$ of the plasmid DNA isolated from the $H$. glycines esophageal gland cell cDNA library in $E$. coli was screened through yeast signal peptide selection. Additional analyses of the remaining gland cell cDNA may produce other putative $H$. glycines secretion genes with potential roles in the nematode parasitism of plants. A functional genomics approach has been initiated that combines EST identification from a representative sample of the gland cell cDNA library with microarray analysis of EST expression in different parasitic stages of $H$. glycines.

\section{MATERIALS AND METHODS}

\section{Microaspiration \\ of nematode esophageal gland cell contents.}

$H$. glycines was cultured on roots of greenhouse-grown soybean (Glycine max) plants (Goverse et al. 1994). The nematode-infected root systems were rinsed and surface sterilized. Parasitic stages of $H$. glycines were hand dissected from soybean roots under a microscope to obtain a representative sample of viable nematodes, ranging from the late second-stage juvenile to young female parasitic stages of $H$. glycines. Individual living nematodes were immobilized in $3 \%$ low-melting-point agarose for microaspiration of esophageal gland cell contents (Shields et al. 1998) under an Eclipse TE 300 inverted microscope (Nikon, Melville, NY, U.S.A.). The tip of an aluminosilicate needle that had been pulled by a Model P-97 automated horizontal micropipette puller (Sutter Instruments, Novato, CA, U.S.A.) to form a 3- to $4-\mu \mathrm{m}$ di- ameter tip opening was filled with $1.0 \mu \mathrm{l}$ of mRNA extraction buffer $(100 \mathrm{mM}$ Tris-HCl, $\mathrm{pH} 7.5 ; 500 \mathrm{mM} \mathrm{LiCl} ; 10 \mathrm{mM}$ EDTA, pH 8.0; 1\% LiDS; and $5 \mathrm{mM}$ dithiothreitol). The base of the needle was held by a Model 5171 micromanipulator (Eppendorf, Hamburg, Germany) with a direct connection of the needle to a CellTram 5176 microinjector-aspirator (Eppendorf). The buffer-filled tip of the needle was used to quickly puncture the immobilized nematode body and enter an esophageal gland cell. Negative pressure on the CellTram unit was used to carefully aspirate the contents of the nematode gland cell directly into the buffer within the needle, and the mixed contents were ejected immediately from the needle into $10 \mu \mathrm{l}$ of mRNA extraction buffer in a microcentrifuge tube and stored at $-80^{\circ} \mathrm{C}$. The majority of the isolated gland cell contents were from the dorsal gland cell, which predominates in the parasitic stages of $H$. glycines, although some subventral gland cell contents also were extracted from the early parasitic stages of $H$. glycines. The immediate mixing of the gland cell contents with the mRNA extraction buffer present in the needle and minimization of the time period from nematode dissection from roots to the aspiration and freezing of gland cell contents were employed to minimize potential mRNA degradation during handling.

\section{mRNA purification and RT-PCR.}

Poly $\mathrm{A}(+)$ RNA from the contents of ten esophageal gland cells representing mixed parasitic stages of $H$. glycines was purified by incubating the pooled contents with $50 \mu \mathrm{g}$ of oligo(dT)-linked paramagnetic beads (Dynal, Lake Success, NY, U.S.A.) in mRNA extraction buffer on a rotator at $22^{\circ} \mathrm{C}$ for $10 \mathrm{~min}$. The mRNA that bound to the beads was rinsed twice with washing buffer I (10 mM Tris- $\mathrm{HCl}, \mathrm{pH} 8.0 ; 0.15 \mathrm{M}$ LiCl; $1 \mathrm{mM}$ EDTA; and $0.1 \%$ LiDS), washing buffer II (10 $\mathrm{mM}$ Tris-HCl, $\mathrm{pH} 8.0 ; 0.15 \mathrm{M} \mathrm{LiCl}$; and $1 \mathrm{mM}$ EDTA), and $1 \times$ RT buffer (50 mM Tris- $\mathrm{HCl}, \mathrm{pH} 8.3 ; 75 \mathrm{mM} \mathrm{KCl}$; and 3 $\mathrm{mM} \mathrm{MgCl}_{2}$ ), respectively. cDNA synthesis was conducted directly from $H$. glycines gland cell mRNA that was attached to the beads with the SuperScript choice system (GIBCOBRL, Gathersburg, MD, U.S.A.), with some modifications. First-strand cDNA was synthesized in a $20-\mu \mathrm{l}$ reaction mixture (50 mM Tris- $\mathrm{HCl}, \mathrm{pH} 8.3 ; 75 \mathrm{mM} \mathrm{KCl} ; 3 \mathrm{mM} \mathrm{MgCl} 2 ; 10 \mathrm{mM}$ dithiothreitol; $0.5 \mathrm{mM}$, each, deoxynucleoside triphosphate [dNTP]; $5 \mathrm{ng}$ of random hexamer; 20 units of RNase inhibitor; and 200 units of Superscript II reverse transcriptase). The random hexamers were annealed to the mRNA template at $25^{\circ} \mathrm{C}$ for $10 \mathrm{~min}$, then reverse transcriptase was added to conduct the cDNA synthesis at $45^{\circ} \mathrm{C}$ for $1 \mathrm{~h}$. Second-strand cDNA was synthesized by adding $140 \mu \mathrm{l}$ of second-strand reaction mixture $(20 \mathrm{mM}$ Tris- $\mathrm{HCl}, \mathrm{pH} 6.9 ; 90 \mathrm{mM} \mathrm{KCl} ; 4.6$ $\mathrm{mM} \mathrm{MgCl} 2 ; 10 \mathrm{mM}\left(\mathrm{NH}_{4}\right)_{2} \mathrm{SO}_{4} ; 150 \mu \mathrm{M} \beta-\mathrm{NAD}^{+}, 0.2 \mathrm{mM}$ [each] dNTP; six units of $E$. coli DNA ligase; 20 units of $E$. coli DNA polymerase I; and 1.2 units of E. coli RNase $\mathrm{H}$ ) with incubation at $16^{\circ} \mathrm{C}$ for $2 \mathrm{~h}$. The double-stranded cDNA obtained was blunt ended by adding one unit of T4 DNA polymerase with incubation for $10 \mathrm{~min}$ at $16^{\circ} \mathrm{C}$. The final reaction mixture was heated at $75^{\circ} \mathrm{C}$ for 15 min to inactivate residual enzyme activities. The blunt-end cDNA was precipitated by $20 \mu \mathrm{g}$ of glycogen (Roche Molecular Biochemicals, Indianapolis, IN, U.S.A.) and ligated to $40 \mathrm{ng}$ of NotI adapters (GIBCO-BRL) at $16^{\circ} \mathrm{C}$ for $16 \mathrm{~h}$. The ligation product was precipitated again by glycogen $(20 \mu \mathrm{g})$ and used as a template 
for PCR amplification. A primer containing the NotI adapter sequence (5'-GTAATGCGAATTCGCGGCCGCGTCGAC-3'), designated EN55, was used to amplify cDNA templates that had been ligated with the adapters. The total pool of adapterligated gland cell cDNA was amplified by PCR in a $100-\mu \mathrm{l}$ reaction mixture $(20 \mathrm{mM}$ Tris- $\mathrm{HCl}, \mathrm{pH} 8.4 ; 50 \mathrm{mM} \mathrm{KCl} ; 1.5$ $\mathrm{mM} \mathrm{MgCl}_{2} ; 0.2 \mathrm{mM}$ [each] dNTP; $0.5 \mu \mathrm{M}$ EN55 primer; and 2.5 units of Taq DNA polymerase [GIBCO-BRL]). The cycling conditions were $72^{\circ} \mathrm{C}$ for $5 \mathrm{~min}$ and $94^{\circ} \mathrm{C}$ for $1 \mathrm{~min}$, followed by 40 cycles of $94^{\circ} \mathrm{C}$ for $1 \mathrm{~min}, 61^{\circ} \mathrm{C}$ for $1 \mathrm{~min}$, $72^{\circ} \mathrm{C}$ for $5 \mathrm{~min}$, and a final reaction of $72^{\circ} \mathrm{C}$ for $10 \mathrm{~min}$. A second PCR was performed because the total amount of initial RT-PCR product was insufficient for the cloning procedure described below. Two microliters of the initial RT-PCR products and the EN55 primer were used for the second amplification. The cycling profiles were $94^{\circ} \mathrm{C}$ for $1 \mathrm{~min}$, followed by 20 cycles of $94^{\circ} \mathrm{C}$ for $1 \mathrm{~min}, 65^{\circ} \mathrm{C}$ for $1 \mathrm{~min}, 72^{\circ} \mathrm{C}$ for $5 \mathrm{~min}$, and a final step of $72^{\circ} \mathrm{C}$ for $10 \mathrm{~min}$.

\section{Cloning cDNA into a signal peptide selection vector.}

The products of the second PCR were cleaned through a PCR purification column (Qiagen, Valencia, CA, U.S.A.) and digested with NotI enzyme (Roche Molecular Biochemicals, Indianapolis, IN, U.S.A.). The NotI-digested PCR products were separated by electrophoresis in a $1 \%$ agarose gel, and cDNA fragments between $200 \mathrm{bp}$ to $3.0 \mathrm{~kb}$ were recovered from the gel and ligated to the dephosphorylated NotIdigested pRK18 secretion signal peptide selection vector (Klein et al. 1996) at a molar ratio of 3:1. The ligation mixture was precipitated by glycogen $(20 \mu \mathrm{g})$, dissolved in $3 \mu \mathrm{l}$ of $\mathrm{dH}_{2} \mathrm{O}$, and used to transform competent DH10B E. coli cells (GIBCO-BRL) by electroporation (Gene Pulser II, Bio-Rad Laboratories, Hercules, CA, U.S.A.), according to the manufacturer's instructions. Ninety-six clones obtained at random from the $E$. coli library of $H$. glycines gland cell cDNA were checked for the size and sequence of cDNA inserts, and the rest of the clones were used for plasmid DNA isolation.

\section{Yeast transformation and signal peptide selection.}

The pRK18 vector provides selection for Ura+ transformants and requires a cDNA insert with secretion signal peptide to be cloned in-frame with the vector invertase gene for functional selection in yeast (Saccharomyces cerevisiae) on sucrose media (Klein et al. 1996). Five to ten percent of the plasmid DNA isolated from the $H$. glycines gland cell cDNA library in $E$. coli was introduced into an invertase-deficient yeast host YT455 ( $\operatorname{suc} \Delta$, ade2-101, ura3-52) by lithium acetate transformation, following a described protocol (Klein et al. 1996). Ura+ yeast transformants were first selected after growth at $30^{\circ} \mathrm{C}$ overnight on solid medium in the absence of uracil $(0.67 \%$ yeast nitrogen base without amino acids, $0.077 \%$-Ura dropout supplement [Clontech Laboratories, Palo Alto, CA, U.S.A.], $2 \%$ glucose, and $2 \%$ agar). The Ura+ transformants were replica transferred to solid sucrose medium ( $1 \%$ yeast extract, $2 \%$ peptone, $2 \%$ sucrose, $2 \%$ agar, and $1 \mu \mathrm{g}$ of antimycin $\mathrm{A}$ per $\mathrm{ml}$ ), and grown at $30^{\circ} \mathrm{C}$ for 3 days. Plasmid DNA was isolated from yeast colonies that survived on the sucrose medium and introduced into $E$. coli $\mathrm{DH} 5 \alpha$ by electroporation for subsequent sequence analysis. DNA sequence was obtained for all cDNA clones that survived (secretion signal peptide) selection on uracil and sucrose media.

\section{Southern blot hybridization.}

Ten micrograms of genomic DNA from $H$. glycines was digested with EcoRI and HindIII, separated by electrophoresis on a $0.8 \%$ agarose gel, and transferred onto Hybond-N Nylon membranes (Amersham Pharmacia Biotech, Piscataway, NJ, U.S.A.), following standard procedures (Sambrook et al. 1989). All cDNA clones obtained after yeast secretion signal peptide selection that had unique DNA sequence were labeled with a PCR-DIG probe synthesis system (Roche Molecular Biochemicals) and used for Southern blot hybridizations to $H$. glycines genomic DNA. About $10 \mathrm{ng}$ of DIG-labeled probe per $\mathrm{ml}$ was used for each hybridization. Hybridizations were performed at $65^{\circ} \mathrm{C}$ overnight, and membranes were washed with $0.5 \times \mathrm{SSC}(1 \times \mathrm{SSC}$ is $0.15 \mathrm{M} \mathrm{NaCl}$ plus $0.015 \mathrm{M}$ sodium citrate) and $0.1 \%$ sodium dodecyl sulfate at $68^{\circ} \mathrm{C}$. Probes that hybridized to $H$. glycines DNA on Southern blots were detected by alkaline phosphatase-conjugated anti-DIG antibody and 5-bromo-4-chloro-3-indolylphosphate toluidinium-nitroblue tetrazolium (BCIP-NBT) substrate color reaction.

\section{In situ hybridization within nematode specimens.}

For in situ hybridizations, DIG-labeled sense and antisense cDNA probes of SY20, SYV46, SYV42, SYV55, SYV80, SYV84, SYS7, SYS16, SYS56, SYS65, SYS79, SYS86, and SYS91 were synthesized by asymmetric PCR amplification. The asymmetric PCR labeling was performed in a $20-\mu \mathrm{l}$ reaction mixture $(20 \mathrm{mM}$ Tris- $\mathrm{HCl}, \mathrm{pH} 8.4 ; 50 \mathrm{mM} \mathrm{KCl} ; 1.5 \mathrm{mM}$ $\mathrm{MgCl} 2 ; 75 \mu \mathrm{M}$ of dATP, dGTP, and dCTP; $26.25 \mu \mathrm{M}$ of DIG11-dUTP; $48.75 \mu \mathrm{M}$ of dTTP; $2 \mathrm{mM}$ of gene-specific forward or reverse primer; and 50 to $200 \mathrm{ng}$ of cDNA template). The gene-specific forward primer for each gene was SY20BamHIF (5'-CGCGGATCCCAGAGAAAGGGTGCCCAAAAACA-3'), SYV46BamHIF (5'-CGCGGATCCCTCTCGGCTTCTACTGGTGACAA-3'), SYV42BamHIF (5'-CGCGGATCCTCCACCGCTGACAAAGGAGTTGA-3'), SYV55BamHIF (5'-CGCGGATCCCTCCCAATGTTCCCAAATTTCTT-3'), SYV80BamHIF (5'-CGCGGATCCCACTGTGCTGTCCAATGTCAACGA-3'), SYV84Finsitu (5'-GGCACGCCTGGACCATCTACA-3'), SYS7BamHIF (5'-CGCGGATCCGTCCGCTGTGTCCCCAACCCAAA-3'), SYS16BamHIF (5'-CGCGGATCCCTCCTCTAGCGATGTGTTGGAAT-3'), SYS56Finsitu (5'-CCGAGATGATGGGTACCAAGAT-3'), SYS65Finsitu (5'-GGCACCAATTAGTCACTGTTAGCA-3'), SYS79Finsitu (5'-GCAACAACCCACTATGCAAATGCA-3'), SYS86BamHIF (5'-CGCGGATCCGAAGTGCTTAGTAATGGAAATTTGA-3'), and SYS91BamHIF (5'-CGCGGATCCGAAGTGCCTGCGCTGAACAAAA-3'). The gene-specific reverse primer for each gene was SY20EcoRIR (5'-CCGGAATTCCCATTTCGTCATAACACCCAAAT-3'), SYV46Rinsitu (5'-GTGGTGGAGCCATTGAGCGATT-3'), SYV42Rinsitu (5'-CTGATAGTCCCTCCAGTTTGAT-3'), SYV55R (5'-CCGTCTGTCGGTCGGTGAT-3'), SYV80Rinsitu (5'-CACGGTATGGTAGGATGTGTAA-3'), SYV84Rinsitu (5'-CTGTTGGTGCTGGTGTAGATGGT-3'), SYS7R (5'-CGGTCGTCATCATACAGTT-3'), SYS16Rinsitu (5'-CGCAGTACAATCGACTTTGATGA-3'), SYS56Rinsitu (5'-GACAGCATTCGCTTCCGTCTT-3'), SYS65Rinsitu (5'-GGGAGAGAGGACGAAGAATTAA-3'), SYS79EcoRIR (5'-CCGGAATTCCCAAAACTGGTACTGCCAACATT-3'), SYS86EcoRIR (5'-CCGGAATTCGGCATATTGATGGGCAATTTGA-3'), and SYS91EcoRIR (5'-CCGGAATTCCGGTGTACCGTTCACACCAAT-3'). 
The PCR cycling profiles were $94^{\circ} \mathrm{C}$ for $2 \mathrm{~min}$, followed by 35 cycles of $94^{\circ} \mathrm{C}$ for $1 \mathrm{~min}, 57^{\circ} \mathrm{C}$ or $61^{\circ} \mathrm{C}$ for $50 \mathrm{~s}, 72^{\circ} \mathrm{C}$ for $90 \mathrm{~s}$, and a final step of $72^{\circ} \mathrm{C}$ for $10 \mathrm{~min}$. The DIG-labeled probe was purified through a PCR purification column (Qiagen) to remove any unincorporated DIG. Mixed parasitic stages of $H$. glycines were collected at 11 to 15 days after inoculation of soybean roots with hatched juveniles by a rootblending and sieving method (De Boer et al. 1999). Parasitic nematodes were fixed in $2 \%$ paraformaldehyde in $\mathrm{M} 9$ buffer (42.3 $\mathrm{mM} \mathrm{Na}_{2} \mathrm{HPO}_{4} ; 22 \mathrm{mM} \mathrm{KH} \mathrm{PO}_{4}, 85.6 \mathrm{mM} \mathrm{NaCl}$, and 1 $\mathrm{mM} \mathrm{MgSO}_{4}$ ) at room temperature, followed by fixation in $0.2 \%$ paraformaldehyde in $0.1 \times \mathrm{M} 9$ buffer at $4^{\circ} \mathrm{C}$ for $24 \mathrm{~h}$. The fixed parasitic nematodes were cut into sections in $0.2 \%$ paraformaldehyde buffer under a dissecting microscope, and nematode sections were permeabilized, as previously described (De Boer et al. 1998), except that a higher proteinase $\mathrm{K}$ concentration ( $2 \mathrm{mg}$ per $\mathrm{ml}$ ) was used to digest the parasitic nematode sections for 50 to $60 \mathrm{~min}$ at room temperature. The nematode sections were hybridized separately with DIGlabeled sense and antisense cDNA probes at $50^{\circ} \mathrm{C}$ overnight. After stringent washes (De Boer et al. 1998), cDNA probes that had hybridized within nematode specimens were detected by alkaline phosphatase-conjugated anti-DIG antibody, BCIPNBT substrate staining, and compound light microscope observation.

\section{3' RACE.}

A $150-\mu l$ pellet of mixed parasitic stages of $H$. glycines was ground in liquid nitrogen into powder and homogenated with $150 \mu \mathrm{l}$ of mRNA extraction buffer. mRNA was isolated with the Dynabeads mRNA DIRECT Kit (Dynal, Lake Success, NY, U.S.A.), according to the manufacturer's instructions. The purified mRNA was further eluted from the oligo(dT)linked paramagnetic beads in $11 \mu \mathrm{l}$ of diethyl pyrocarbonatetreated water and used for reverse transcription with the $3^{\prime}$ RACE system (GIBCO-BRL). Abridged universal amplification primer (5'-GGCCACGCGTCGACTAGT-AC-3') and $5^{\prime}$ end gene-specific primer of SY20F (5'-GGATTGGGAGGAATTGAGCTGAA-3'), SYV46BamHIF (5'-CGCGGATCCCTCTCGGCTTCTACTGGTGACAA-3'), SYV42BamHIF (5'CGCGGATCCTCCACCGCTGACAAAGGAGTTGA-3'), SYV55BamHIF (5'-CGCGGATCCCTCCCAATGTTCCCAAATTTCTT-3'), SYV80BamHIF (5'-CGCGGATCCCACTGTGCTGTCCAATGTCAACGA-3'), SYV84F (5'-CCAACAGGCACGCCTGGACCAT-3'), SYS7BamHIF (5'-CGCGGATCCGTCCGCTGTGTCCCCAACCCAAA-3'), SYS16F (5'GCGGAAAAAGAGACTTGCGATA-3'), SYS56Finsitu (5'CCGAGATGATGGGTACCAAGAT-3'), SYS79Finsitu (5'GCAACAACCCACTATGCAAATGCA-3'), or SYS86F (5'GGGACGAAGGAATCGTTCAAAT-3') were used for PCR amplification. The amplified PCR products were cloned into pCR2.1 vector (Invitrogen, Carlsbad, CA, U.S.A.) for sequencing.

\section{ACKNOWLEDGMENTS}

This research was supported by the United Soybean Board under grant 400-40-22, USDA-NRICGP grant 98-35302-6881, and the North Carolina Agricultural Research Service.

\section{LITERATURE CITED}

Atkinson, H. J., Harris, P. D., Halk, E. J., Novitski, C., Leighton-Sands, J., Nolan, P., and Fox, P. C. 1988. Monoclonal antibodies to the soya bean cyst nematode, Heterodera glycines. Ann. Appl. Biol. 112:459469.

Bardwell, J. C. 1994. Building bridges: Disulphide bond formation in the cell. Mol. Microbiol. 14:199-205.

Brew, K., Dinakarpandian, D., and Nagase, H. 2000. Tissue inhibitors of metalloproteinases: Evolution, structure and function. Biochim. Biophys. Acta 1477:267-283.

C. elegans Sequencing Consortium. 1998. Genome sequence of the nematode $C$. elegans: A platform for investigating biology. Science 282:2012-2018.

Chandrashekar, R., and Mehta, K. 2000. Transglutaminase-catalyzed reactions in the growth, maturation and development of parasitic nematodes. Parasitol. Today 16:11-17.

Chandrashekar, R., Tsuji, N., Morales, T., Ozols, V., and Mehta, K. 1998. An ERp60-like protein from the filarial parasite Dirofilaria immitis has both transglutaminase and protein disulfide isomerase activity. Proc. Natl. Acad. Sci. USA 95:531-536.

Davis, E. L., Aron, L. M., Pratt, L. H., and Hussey, R. S. 1992. Novel immunization procedures used to develop monoclonal antibodies that bind to specific structures in Meloidogyne spp. Phytopathology 82:1244-1250.

Davis, E. L., Allen, R., and Hussey, R. S. 1994. Developmental expression of esophageal gland antigens and their detection in stylet secretions of Meloidogyne incognita. Fundam. Appl. Nematol. 17:255-262.

Davis, E. L., Hussey, R. S., Baum, T. J., Bakker, J., Schots, A., Rosso, M.-N., and Abad, P. 2000. Nematode parasitism genes. Annu. Rev. Phytopathol. 38:365-396.

De Boer, J. M., Smant, G., Goverse, A., Davis, E. L., Overmars, H. A., Pomp, H., Van Gent-Pelzer, M., Zilverentant, J. F., Stokkermans, J. P. W. G., Hussey, R. S., Gommers, F. J., Bakker, J., and Schots, A. 1996. Secretory granule proteins from the subventral esophageal glands of the potato cyst nematode identified by monoclonal antibodies to a protein fraction from second-stage juveniles. Mol. Plant Microbe Interact. 9:39-46.

De Boer, J. M., Yan, Y., Smant, G., Davis, E. L., and Baum, T. J. 1998. In situ hybridization to messenger RNA in Heterodera glycines. J. Nematol. 30:309-312.

De Boer, J. M., Yan, Y., Wang, X., Smant, G., Hussey, R. S., Davis, E. L., and Baum, T. J. 1999. Developmental expression of secretory $\beta$ 1,4-endoglucanases in the subventral esophageal glands of Heterodera glycines. Mol. Plant Microbe Interact. 12:663-669.

Ding, X., Shields, J., Allen, R., and Hussey, R. S. 1998. A secretory cellulose-binding protein cDNA cloned from the root-knot nematode (Meloidogyne incognita). Mol. Plant-Microbe Interact. 11:952-959.

Endo, B. Y. 1987. Ultrastructure of esophageal gland secretory granules in juveniles of Heterodera glycines. J. Nematol. Soc. Wash. 19:469483.

Endo, B. Y. 1993. Ultrastructure of subventral gland secretory granules in parasitic juveniles of the soybean cyst nematode, Heterodera glycines. J. Helminthol. 60:22-34.

Goverse, A., Davis, E. L., and Hussey, R. S. 1994. Monoclonal antibodies to the esophageal glands and stylet secretions of Heterodera glycines. J. Nematol. 26:251-259.

Hussey, R. S. 1989a. Disease-inducing secretions of plant-parasitic nematodes. Annu. Rev. Phytopathol. 27:123-141.

Hussey, R. S. 1989b. Monoclonal antibodies to secretory granules in esophageal glands of Meloidogyne species. J. Nematol. 21:392-398.

Hussey, R. S., and Grundler, F. M. 1998. Nematode parasitism of plants. Pages 213-243 in: Physiology and Biochemistry of Free-Living and Plant Parasitic Nematodes. R. N. Perry and D. J. Wright, eds. CAB International Press, England.

Klein, R. D., Gu, Q., Goddard, A., and Rosenthal, A. 1996. Selection for genes encoding secreted proteins and receptors. Proc. Natl. Acad. Sci. USA 93:7108-7113.

Lambert, K. N., Allen, K. D., and Sussex, I. M. 1999. Cloning and characterization of an esophageal-gland-specific chorismate mutase from the phytoparasitic nematode Meloidogyne javanica. Mol. Plant Microbe Interact. 12:328-336.

L'Etoile, N. D., and Bargmann, C. I. 2000. Olfaction and odor discrimination are mediated by the $C$. elegans guanylyl cyclase $o d r-1$. Neuron 
25:575-586.

Lucas, K. A., Pitari, G. M., Kazerounian, S., Ruiz-Stewart, I., Park, J. Schulz, S., Chepenik, K. P., and Waldman, S.A. 2000. Guanylyl cyclases and signaling by cyclic GMP. Pharmacol. Rev. 52:375-413.

Mazzarella, R., and Green, M. 1987. ERp99, an abundant conserved glycoprotein of the endoplasmic reticulum, is homologous to the 90$\mathrm{kDa}$ heat shock protein (hsp90) and the 94-kDa glucose regulated protein (GRP94). J. Biol. Chem. 262:8875-8883.

Nakai, K., and Horton, P. 1999. PSORT: A program for detecting sorting signals in proteins and predicting their subcellular localization. Trends Biochem. Sci. 24:34-35.

Nielsen, H., Engelbrecht, J., Brunak, S., and Von Heijne, G. 1997. Identification of prokaryotic and eukaryotic signal peptides and prediction of their cleavage sites. Protein Eng. 10:1-6.

Qin, L., Overmars, H., Helder, J., Popeijus, H., Van der Voort, J. R., Groenink, W., Van Koert, P., Schots, A., Bakker, J., and Smant, G. 2000. An efficient cDNA-AFLP-based strategy for the identification of putative pathogenicity factors from the potato cyst nematode Globodera rostochiensis. Mol. Plant-Microbe Interact. 13:830836.

Sambrook, J., Fritsch, E. F., and Maniatis, T. 1989. Molecular Cloning: A Laboratory Manual, 2nd ed. Cold Spring Harbor Laboratory, Cold Spring Harbor, NY, U.S.A.

Shields, J. P., Ding, X., and Hussey, R. S. 1998. Microaspiration of esophageal gland cell contents from plant-parasitic nematodes. J. Nematol. 30:515.

Smant, G., Stokkermans, J. P. W. G., Yan, Y., De Boer, J. M., Baum, T.
J., Wang, X., Hussey, R. S., Gommers, F. J., Henrissat, B., Davis, E. L., Helder, J., Schots, A., and Bakker, J. 1998. Endogenous cellulases

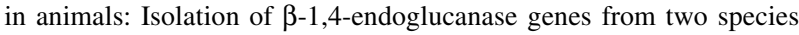
of plant-parasitic cyst nematodes. Proc. Natl. Acad. Sci. USA 95:4906-4911.

Stover, C. K., Pham, X. Q., Erwin, A. L., Mizoguchi, S. D., Warrener, P., Hichey, M. J. et al. 2000. Complete genome sequence of Pseudomonas aeruginosa PA01, an opportunistic pathogen. Nature 406:959964.

Von Heijne, G. 1985. Signal sequences, the limits of variation. J. Mol. Biol. 184:99-105.

Wang, X., Meyers, D., Yan, Y., Baum, T., Smant, G., Hussey, R., and Davis, E. 1999. In planta localization of a $\beta-1,4$-endoglucanase secreted by Heterodera glycines. Mol. Plant-Microbe Interact. 12:64-67.

Wyss, U. 1992. Observations on the feeding behaviour of Heterodera schachtii throughout development, including events during moulting. Fundam. Appl. Nematol. 15:75-89.

Wyss, U., and Zunke, U. 1986. Observations on the behaviour of second stage juveniles of Heterodera schachtii inside host roots. Rev. Nematol. 9:153-165.

Yan, Y., Smant, G., Stokkermans, J., Qin, L., Helder, J., Baum, T., Schots, A., and Davis, E. 1998. Genomic organization of four B-1,4endoglucanase genes in plant-parasitic cyst nematodes and its evolutionary implications. Gene 220:61-70.

Yu, S., Avery, L., Baude, E., and Garbers, D. L. 1997. Guanylyl cyclase expression in specific sensory neurons: A new family of chemosensory receptors. Proc. Natl. Acad. Sci. USA 94:3384-3387. 